\title{
Chemoenzymatic Epoxidation of Alkenes and Reusability Study of the Phenylacetic Acid
}

\author{
Emilia Abdulmalek, ${ }^{1}$ Mahashanon Arumugam, ${ }^{1}$ Hanis Nabillah Mizan, ${ }^{1}$ \\ Mohd. Basyaruddin Abdul Rahman, ${ }^{1}$ Mahiran Basri, ${ }^{1}$ and Abu Bakar Salleh ${ }^{2}$ \\ ${ }^{1}$ Department of Chemistry, Faculty of Science, Universiti Putra Malaysia, 43400 Serdang, Selangor, Malaysia \\ ${ }^{2}$ Department of Biochemistry, Faculty of Biotechnology and Biomolecular Science, Universiti Putra Malaysia, \\ 43400 Serdang, Selangor, Malaysia
}

Correspondence should be addressed to Emilia Abdulmalek; emilia@science.upm.edu.my

Received 31 August 2013; Accepted 24 October 2013; Published 27 January 2014

Academic Editors: A. Bekatorou, A. Geng, and G. B. Shul'pin

Copyright (C) 2014 Emilia Abdulmalek et al. This is an open access article distributed under the Creative Commons Attribution License, which permits unrestricted use, distribution, and reproduction in any medium, provided the original work is properly cited.

Here, we focused on a simple enzymatic epoxidation of alkenes using lipase and phenylacetic acid. The immobilised Candida antarctica lipase B, Novozym 435 was used to catalyse the formation of peroxy acid instantly from hydrogen peroxide $\left(\mathrm{H}_{2} \mathrm{O}_{2}\right)$ and phenylacetic acid. The peroxy phenylacetic acid generated was then utilised directly for in situ oxidation of alkenes. A variety of alkenes were oxidised with this system, resulting in 75-99\% yield of the respective epoxides. On the other hand, the phenylacetic acid was recovered from the reaction media and reused for more epoxidation. Interestingly, the waste phenylacetic acid had the ability to be reused for epoxidation of the 1-nonene to 1-nonene oxide, giving an excellent yield of $90 \%$.

\section{Introduction}

Epoxides are an important class of compounds in many industrial processes and often made by the epoxidation of alkenes [1]. These epoxides are valuable intermediates for laboratory syntheses as well as chemicals production as they can be easily transformed into a required functionality by means of regioselective ring opening reactions [2]. In addition, epoxides are also used as raw materials in many manufacturing industries, with some epoxides even exhibiting numerous biological activities $[3,4]$.

Many of these epoxides are synthesised using epoxidising agents such as metal catalysts or strong mineral acids; however, the yields of epoxide tend to be low and accompanied by side product formation as well as corrosion problems [5]. The synthesis of epoxides has gained more interest when enzymes began to be used as a catalyst with regards to the creation of environmentally friendly process [6]. The use of biological catalysts like lipases has its own advantage such as high regioselectivity, which can lead mainly to high purity in epoxide production $[7,8]$.
Prilezhaev epoxidation of alkenes with a peroxy acid is the most common method used in research laboratories and industries nowadays $[9,10]$. Even though the Prilezhaev epoxidation protocol together with the lipase has been widely used for the manufacture of epoxides, the employment of peroxy acids is not a hygienic method because equivalent amount of acid waste is generated [11]. Therefore, special attention has to be given to the accumulation of unreacted peroxy acid, which could result in contamination of the end product and possible enzyme deactivation $[11,12]$.

Lately, we reported some of our findings on epoxidation of alkene using phenylacetic acid $[13,14]$. The phenylacetic acid emerged as one of the effective perhydrolysis substrate, since a high stability of lipase was observed during the epoxidation process. As part of our ongoing research, we are interested in screening more variety of alkenes with phenylacetic acid as an oxygen carrier and Novozym 435-an immobilised Candida antarctica lipase B as a biocatalyst for the epoxidation process. Moreover, an examination was conducted to recover and reuse the excess phenylacetic acid from the reaction mixture in designing a more cheap, practical, 
safe, and environmentally friendly method to oxidise the alkenes.

\section{Materials and Methods}

2.1. Materials. 1-Nonene (98\%), 1-heptene (97\%), styrene (99\%), cyclohexene (99\%) and 1-methylcyclohexene (97\%), cyclohexene oxide (standard), and chloroform- $d$ were obtained from Sigma-Aldrich, USA. 1-Methylcyclohexene oxide (standard) was bought from Tokyo Chemical Industry, Japan. Chloroform, ethyl acetate, and toluene were purchased from Fisher Scientific, UK. Acetone, $\mathrm{H}_{2} \mathrm{O}_{2}(30 \%$, w/w), and phenylacetic acid were purchased from Merck, Germany. A commercially known biocatalyst, CALB, immobilised on a macroporous acrylic resin (Novozym 435) was obtained from Novozymes Corporation, Denmark. The standards for 1-nonene oxide and 1-heptene oxide were prepared and identified as described by Rusch Gen Klaas and Warwel [15]. For GC-MS analysis, ethyl acetate and chloroform HPLCgrade were procured from Fisher Scientific, UK.

\subsection{Experimental Procedures for Chemoenzymatic Epoxida-} tion of Alkenes. In a typical experiment, epoxidation was carried out in a $50 \mathrm{~mL}$ capacity round bottom flask. Initially, alkene (1-nonene) $(0.6 \mathrm{mmol})$ was evenly mixed in chloroform $(10 \mathrm{~mL})$ to form a constant solution. Neatly, phenylacetic acid $(8.8 \mathrm{mmol})$ and Novozym $435(1.7 \% \mathrm{wt} / \mathrm{wt}, 19.9 \mathrm{mg})$ were added to the mixture. The reaction was initiated by adding $\mathrm{H}_{2} \mathrm{O}_{2}$ (30\% wt/wt, $4.4 \mathrm{mmol}$ ) in one step using an autotitrator (Metrohm, New Zealand). Ultimately, the reaction was carried out in a water bath shaker (Hotech Instrument, Taiwan) at temperature $\left(35^{\circ} \mathrm{C}\right)$, time $(12 \mathrm{~h})$, and speed $(250 \mathrm{rpm})$. For all experiments, the epoxide was synthesised at least in duplicate.

2.3. Sample Preparation for Quantitative Analysis. Samples were withdrawn at appropriate time intervals for a quantitative analysis. A $0.1 \mathrm{~mL}$ sample was diluted 100 times by mixing $9.9 \mathrm{~mL}$ of ethyl acetate (HPLC grade) and filtered using $0.45 \mu \mathrm{M}$ (Advantec, Japan) membrane filters before analysis. The yield was then determined by GC-MS (Agilent Technology, USA) and compared with an authentic standard prepared from the previous literature.

2.4. Quantitative Method. Analysis of epoxide yield was performed by using GC (Agilent Technology model 7890, GC system) coupled with a mass spectrometer, model 5975 C inert-MSD, with triple axis detector operated in the electron emission (EI) mode. The compound was separated on a $(30.0 \mathrm{~m} \times 0.25 \mathrm{~mm}) \mathrm{HP}-5 \mathrm{~ms}$ column coated with $0.25 \mu \mathrm{m}$ film thickness of fused silica gel with 5\% phenyl methylpolysiloxane.

2.5. Isolation and Purification of Phenylacetic Acid. The isolation of phenylacetic acid was performed using a $125 \mathrm{~mL}$ separating funnel. Initially, the reaction mixture was washed with distilled water to remove the remaining $\mathrm{H}_{2} \mathrm{O}_{2}$. After the phase separation, the organic layer was extracted out and dried over $5 \%(\mathrm{w} / \mathrm{w})$ of $\mathrm{Na}_{2} \mathrm{SO}_{3}$ and $\mathrm{Na}_{2} \mathrm{SO}_{4}$, respectively. The crude mixture was purified by silica gel column chromatography with a mobile phase containing hexane and ethyl acetate $(3: 2)$. The purified combined fractions were evaporated under vacuum by rotary evaporator (Buchi, Switzerland). The phenylacetic acid was then characterised with GC-MS, ${ }^{1} \mathrm{H}$, and ${ }^{13} \mathrm{C}$ NMR and compared with the reported data.

2.6. Spectroscopic Characterisation. Identification of final epoxide product was performed using spectroscopic analysis and matched with the reported data. The epoxide was periodically characterised by FT-IR (PerkinElmer-model 1650, USA) and GC-MS (Agilent Technology, USA) (see Supplementary Material available online at http://dx.doi.org/10.1155/ 2014/756418). The structure elucidation of epoxide was confirmed with ${ }^{1} \mathrm{H}$ and ${ }^{13} \mathrm{C}$ NMR (Jeol ECA, Japan). The optical rotation of the epoxide was determined by polarimeter (Jasco-model 2000, Japan).

\section{Results and Discussion}

3.1. Mechanism of Chemoenzymatic Perhydrolysis Reaction. In the enzyme-catalysed epoxidation reaction, $\mathrm{H}_{2} \mathrm{O}_{2}$ acts as oxidising agent and converts the carboxylic acid into peroxy acid. In this study, the reaction was initiated using lipase Novozym 435 to catalyse the production of phenylacetic peroxy acid (the oxygen carrier) via the perhydrolysis of phenylacetic acid. Scheme 1 describes the general reaction mechanism of lipase-catalysed perhydrolysis reaction.

The lipase catalytic site contains a catalytic triad composed of a histidine (His), serine (Ser), and an aspartate (Asp)/glutamic acid residue [16]. These three essential amino acids, located closely at the active site, play a major role in the cleaving ability of the lipase [17]. The serine amino acid has an $\mathrm{OH}$ group and serves as a nucleophile on the active site of lipase, thus forming a strong hydrogen bond between the "N" atoms in the imidazole ring of the histidine.

In the initial step, the lone pair electrons on the $\mathrm{N}$ atom of the histidine have the potential to accept the hydroxyl proton from the serine. This is due to a carboxyl residue of the aspartate/glutamic acid that forms a hydrogen bond with the imidazole ring of the histidine, making the $\mathrm{N}$ atom mentioned above be very electronegative. The serine residue makes a nucleophilic attack on a carbonyl carbon of the acyl group that belongs to the substrate $\left(\mathrm{R}^{1} \mathrm{COOH}\right)$ to form an intermediate known as tetrahedral intermediate 1 . The tetrahedral intermediate $\mathbf{1}$ is stabilised by an oxyanion hole interaction, which is found in all lipases.

In the second step, the bond connecting carbon and oxygen atoms in the carboxylic acid is broken. The covalent electron on the oxygen thus moves to attack the hydrogen of the histidine and breaks the $\mathrm{N}-\mathrm{H}$ linkage. The histidine group enhances the proton transfer from the hydroxyl group resulting in the release of a water molecule $(\mathrm{HOH})$. When a $\mathrm{H}_{2} \mathrm{O}_{2}$ molecule comes, it attacks the carbonyl carbon of the serine complex resulting in the movement of the $\pi$ electrons of the double bonds to oxygen, thus making it negative. Once again, a tetrahedral intermediate $\mathbf{2}$ is formed. In a final step, the bond between the serine and carbon of the acid moves to attack the proton of the histidine. As a result, the serine 

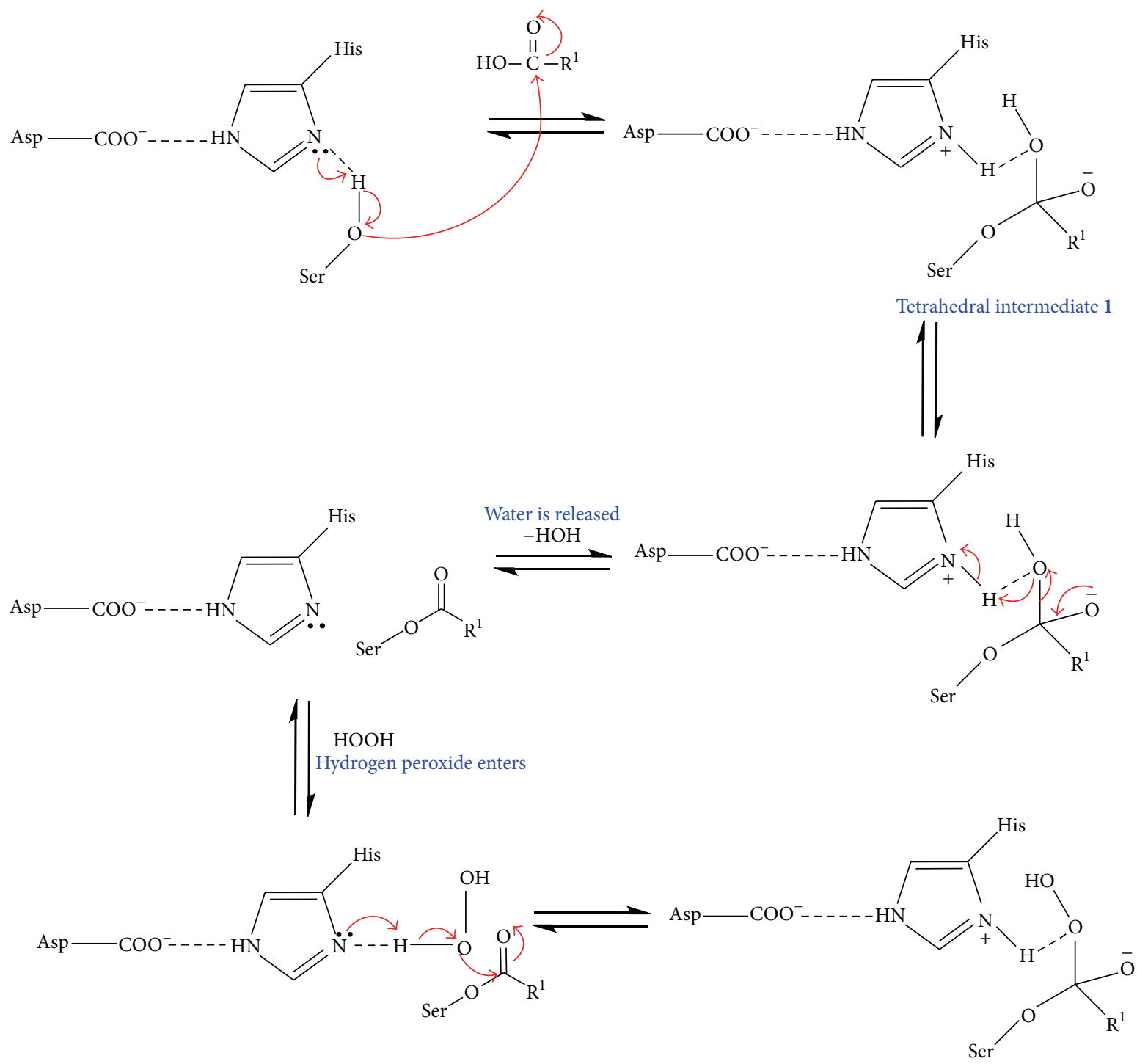

Tetrahedral intermediate $\mathbf{2}$

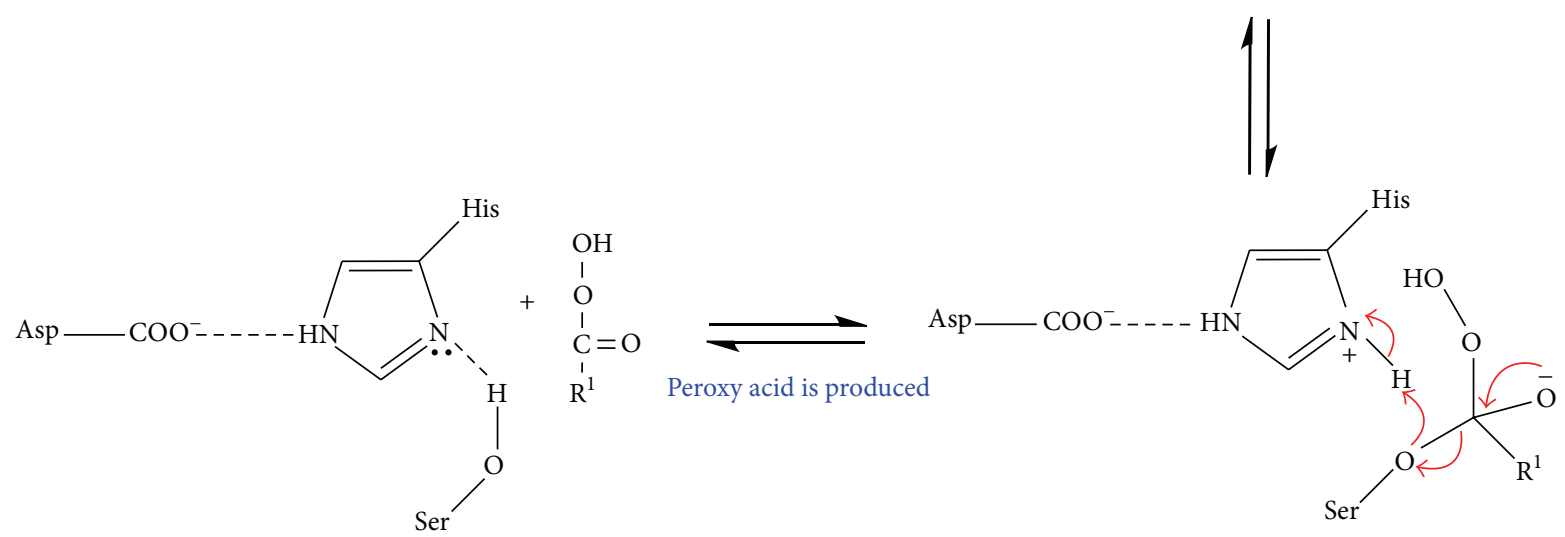

SCHEME 1: Mechanism of lipase-catalysed perhydrolysis reaction [17]. 


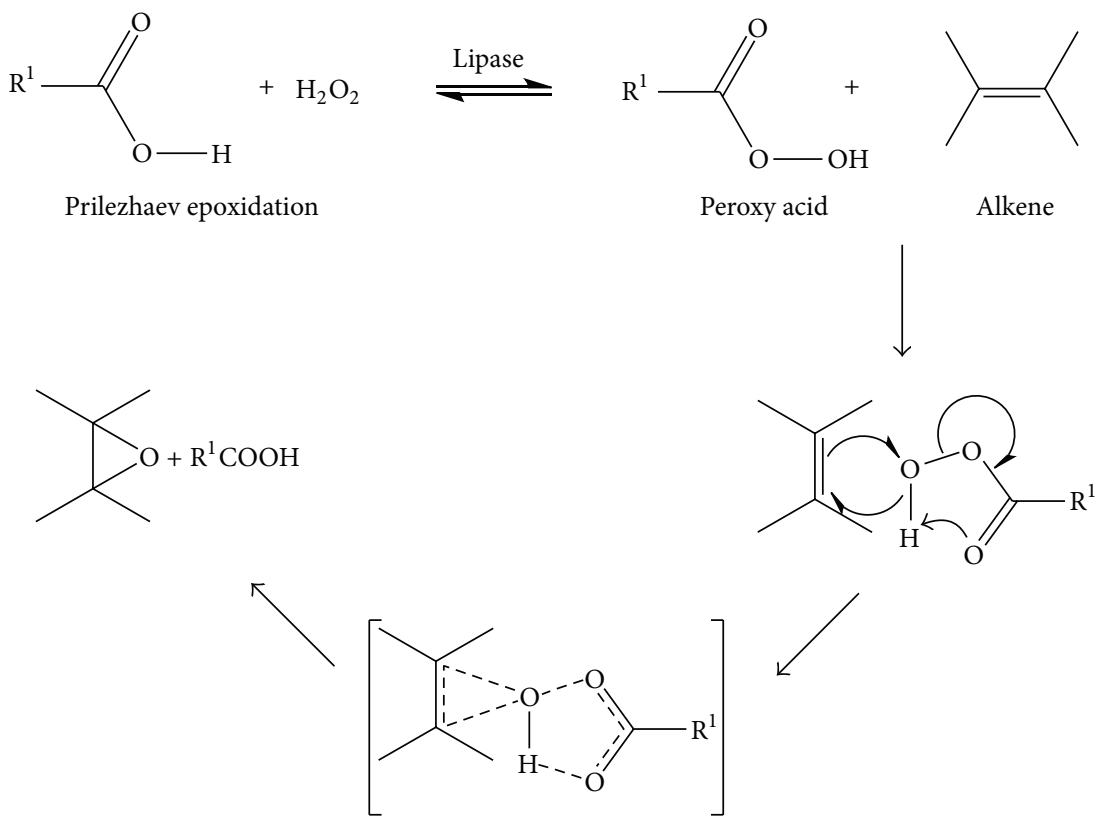

Scheme 2: Mechanism of Prilezhaev epoxidation of alkene.

residue is ejected, and the product peroxy acid $\left(\mathrm{R}^{1} \mathrm{COOOH}\right)$ is released.

\subsection{Mechanism of Chemoenzymatic Epoxidation Reaction.} The in situ produced peroxy acid then oxidises the alkene, affording the respective epoxide and regenerating the carboxylic acid. The reaction mechanism for Prilezhaev epoxidation of alkenes is shown in Scheme 2.

3.3. Chemo Enzymatic Epoxidation of Alkenes. It is interesting to underline that all chemo enzymatic epoxidation reactions performed in the presence of phenylacetic acid gave good results, probably due to lipase stabilisation in mild phenylacetic acid. The summary of the epoxidation of different alkenes with Novozym $435, \mathrm{H}_{2} \mathrm{O}_{2}$, and phenylacetic acid is shown in Table 1. Upon the oxidation of these alkenes via Prilezhaev epoxidation technique, epoxide yields of 7599\% were achieved with purities more than $90 \%$ in the gas chromatogram. Remarkably, the new developed system was efficient and convenient, since the epoxidation of the tested terminal alkenes was very fast in producing their respective epoxides with yields above $90 \%$.

The yield of styrene oxide is lower than aliphatic epoxides, which was probably due to acid-catalysed hydrolysis and isomerisation of styrene oxide to diol and benzaldehyde, respectively. This phenomenon is similar to other lipase-catalysed epoxidation systems $[18,19]$. In the case of 1-methylcyclohexene, incomplete yield was obtained within $12 \mathrm{~h}$ of reaction time. For this reason, the reaction time was prolonged to $16 \mathrm{~h}$ whereby higher yield of 1-methylcyclohexene oxide (90\%) was achieved. Meanwhile, the epoxidation of cyclohexene with peroxy phenylacetic acid led to a moderate yield (75\%) and selective cyclohexene oxide. The lower yield of cyclohexene oxide compared to other epoxide was because of the ring opening reaction of cyclohexene oxide to diol $[8,20]$.
It was worth mentioning that some authors formerly have reported that the lipase is not able at all to perform epoxidation reaction in one single addition of $\mathrm{H}_{2} \mathrm{O}_{2}$ [15]. However, this study demonstrated that chemo-enzymatic epoxidation was feasible with a single addition of $\mathrm{H}_{2} \mathrm{O}_{2}$, which provided an operational stability of lipase and thus promoted the lipase-mediated protocol in industrial application.

3.4. Recyclability of Phenylacetic Acid. Subsequent to epoxidation of various alkenes, recyclability of phenylacetic acid was studied in order to reduce the acid waste produced during the epoxidation reaction. In this study, phenylacetic acid was successfully isolated and purified from the reaction mixture and subjected to characterization with GC-MS and NMR. The GC chromatogram of epoxidation of 1-nonene using recycled phenylacetic acid is shown in Figure 1.

Only a small amount of recycled phenylacetic acid ( $0.3 \mathrm{~g})$ was obtained after a series of isolation and purification steps. The result demonstrated that the highest yield of $90 \% 1-$ nonene oxide was achieved when phenylacetic acid was reused for the epoxidation reaction. This proved that phenylacetic acid is a very efficient perhydrolysis substrate as it can be reused for several epoxidation reactions.

In brief, the epoxidation reaction by lipase-mediated perhydrolysis of phenylacetic acid is a practical method, especially suitable for acid sensitive alkenes. The recyclability result exemplifies the importance of perhydrolysis substrate selection in chemo-enzymatic epoxidation of alkenes as this would control the cost of production and also promote the eco-friendly chemo-enzymatic epoxidation needs on both laboratory and industrial scales.

3.5. Comparative Study. Remarkably, the new developed system was efficient and convenient, since the epoxidation of the tested alkenes was rapid in producing the respective 
TABLE 1: Novozym 435-mediated epoxidation of alkenes.

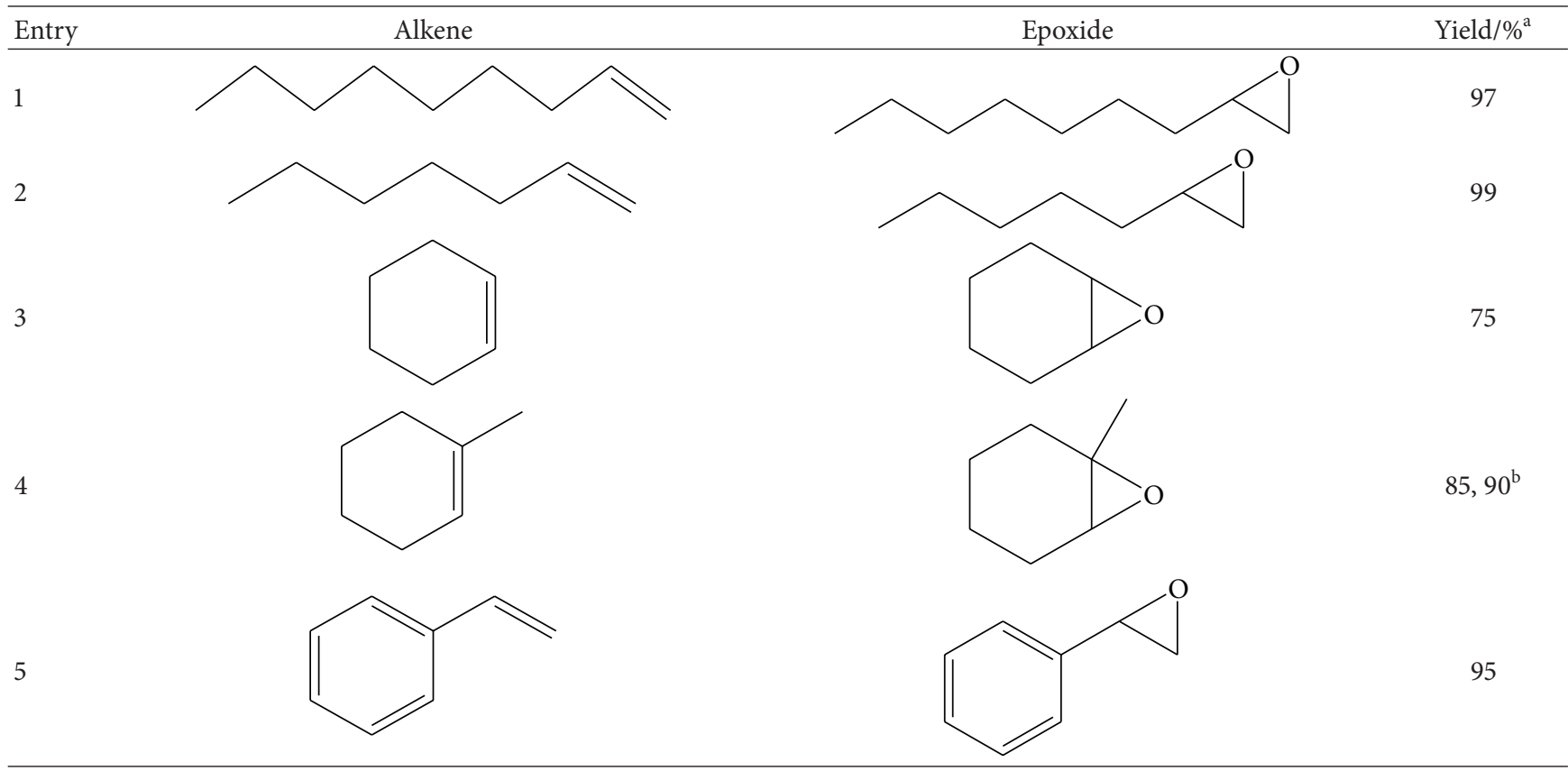

${ }^{\mathrm{a}}$ Reaction was performed in $10 \mathrm{~mL}$ of chloroform at temperature $\left(35^{\circ} \mathrm{C}\right)$ with alkene $(0.6 \mathrm{mmol})$, phenylacetic acid $(8.8 \mathrm{mmol}), \mathrm{H}_{2} \mathrm{O}_{2}(30 \% \mathrm{wt} / \mathrm{wt}, 4.4 \mathrm{mmol})$, Novozym 435 (1.7\% wt/wt, $19.9 \mathrm{mg})$ and shaken at $250 \mathrm{rpm}$ for $12 \mathrm{~h}$. The yields were determined by GC-MS SIM method.

${ }^{\mathrm{b}}$ The epoxidation yield was obtained after $16 \mathrm{~h}$ of reaction time.

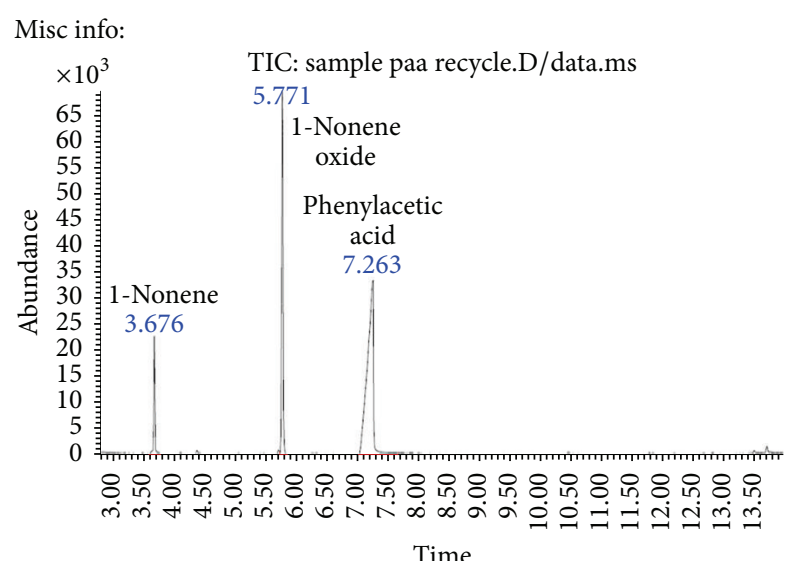

FIGURE 1: The GC chromatogram of epoxidation of 1-nonene using recycled phenylacetic acid.

epoxides with yields above 90\%. This implied the promise of practical application of this methodology. In particular, the epoxidation of styrene was found to be over $90 \%$ in $12 \mathrm{~h}$ as compared to other systems using dimethyl carbonate and ethyl acetate, which required at least $6 \mathrm{~h}$ dosing of $\mathrm{H}_{2} \mathrm{O}_{2}$ and additional $16 \mathrm{~h}$ of stirring time [15].

In addition, our method required $50 \%$ less $\mathrm{H}_{2} \mathrm{O}_{2}$ concentration and $20 \mathrm{~h}$ less time but produced almost $7 \%$ higher epoxide in comparison with the epoxidation of styrene in lactone [21]. On the other hand, our method also required 50\% less $\mathrm{H}_{2} \mathrm{O}_{2}$ concentration and 70\% less enzyme but gave 20\% higher styrene oxide yield in comparison to Rusch Gen Klaas and Warwel [15] epoxidation that used dimethyl carbonate and ethyl acetate as perhydrolysis substrates. Furthermore, in comparison with the system performed in the urea- $\mathrm{H}_{2} \mathrm{O}_{2}$ and ethyl acetate [22], a 25\% higher yield and much shorter reaction time were required for the epoxidation of styrene in our system with $10 \%$ less enzyme.

3.6. Spectroscopic Data. 1-Nonene oxide: the analytical procedure was performed as reported by Abdulmalek et al. [13].

1-Nonene Oxide. Yield 97\%; pale yellowish viscous oil. MS $m / z$ (rel. int.): $142\left[\mathrm{M}^{+}\right]$(0.1), 113 (5), 99 (10), 85 (13), 81 (32), 71 (100), 69 (40), 68 (33), 67 (30), 58 (37), 57 (29), 56 (40), 55.1 (61); GC-MS $t_{R}=5.726 \mathrm{~min} ;[\propto]_{D}^{20}=0$ (c 0.02, ethyl acetate).

1-Heptene Oxide. The standard for 1-heptene oxide was prepared according to a method reported by Rusch Gen Klaas and Warwel [15]. The inlet temperature was set at $260^{\circ} \mathrm{C}$. The GC oven was initially maintained at temperature $40^{\circ} \mathrm{C}$ for $1 \mathrm{~min}$; then it increased to $50^{\circ} \mathrm{C}$ at $1^{\circ} \mathrm{C} / \mathrm{min}$, was held for $12 \mathrm{~min}$, and subsequently ramped to $260^{\circ} \mathrm{C}$ at $20^{\circ} \mathrm{C} / \mathrm{min}$. Identification of compounds was carried out with full SCAN mode $(\mathrm{m} / z)$ in the range of $40-160 \mathrm{amu}$. The SIM analysis was performed by observing ions at $(\mathrm{m} / z=29.1,41.1,42.1$, $55.1,56.1)$ for 1 -heptene and $(m / z=41.1,55.1,56.1,71.1)$ for 1-heptene oxide, respectively.

1-Heptene Oxide. Yield 99\%; colourless oil; IR $v_{\max }\left(\mathrm{cm}^{-1}\right)$ : 2928, 1718, 1452, 1385, 1248, 1157, 981, 756; ${ }^{1} \mathrm{H}$ NMR $(500 \mathrm{MHz}$, $\left.\mathrm{CDCl}_{3}\right) \delta 0.83\left(3 \mathrm{H}, \mathrm{t}, J=7.0, \mathrm{CH}_{3}\right), 1.15-1.50\left(8 \mathrm{H}, \mathrm{m}, \mathrm{CH}_{2}-\right.$ $\left.\mathrm{CH}_{2}\right), 2.41\left(1 \mathrm{H}, \mathrm{dd}, J=2.8,5.0, \mathrm{CHOCH}_{\mathrm{A}} \mathrm{H}_{\mathrm{B}}\right), 2.70(1 \mathrm{H}, \mathrm{dd}$, $\left.J=4.0,5.0, \mathrm{CHOCH}_{\mathrm{A}} \mathrm{H}_{\mathrm{B}}\right), 2.83-2.87\left(1 \mathrm{H}\right.$, br.m, $\left.\mathrm{CHOCH}_{2}\right)$ 
[23]; ${ }^{13} \mathrm{C}-\mathrm{NMR}\left(125.7 \mathrm{MHz}, \mathrm{CDCl}_{3}\right) \delta 14.0,22.6,25.6,31.6$, 32.4, 47.2, 52.5 [24]; MS m/z (rel. int): $114\left[\mathrm{M}^{+}\right](0.2), 113$ (0.3), 85 (12), 71 (100), 67 (15), 58 (41), 56 (50), 55 (46), 43 (34), 42 (34), 41 (69); GC-MS $t_{R}=11.688 \mathrm{~min} ;[\propto]_{D}^{20}=0$ (c 0.03, ethyl acetate).

Styrene Oxide. The inlet temperature was set at $280^{\circ} \mathrm{C}$. The $\mathrm{GC}$ oven temperature was $50^{\circ} \mathrm{C}$ to $260^{\circ} \mathrm{C}$ at $15^{\circ} \mathrm{C} / \mathrm{min}$ for $0 \mathrm{~min}$. A full SCAN data $(\mathrm{m} / z)$ was performed in a mass range of 45-160. In SIM method, quantitation for styrene and styrene oxide was performed by monitoring the group of ions $(m / z=78.1,103.1,104.1)$ and $(m / z=89.1,90.1,91.1,119.1)$, correspondingly. The purified product was then characterised with FT-IR, GC-MS, and ${ }^{1} \mathrm{H}$ and ${ }^{13} \mathrm{C}$ NMR.

Styrene Oxide. Yield 95\%; colourless liquid; IR $\nu_{\max }\left(\mathrm{cm}^{-1}\right)$ : 3039, 2990, 1606, 1476, 1254, 984, 873, 812; ${ }^{1} \mathrm{H}-\mathrm{NMR}$ $\left(500 \mathrm{MHz}_{\mathrm{CDCl}}\right) \delta 2.81\left(1 \mathrm{H}, \mathrm{dd}, J=2.6,5.5, \mathrm{CHOCH}_{\mathrm{A}} \mathrm{H}_{\mathrm{B}}\right)$, $3.15\left(1 \mathrm{H}, \mathrm{dd}, J=4.1,5.5, \mathrm{CHOCH}_{\mathrm{A}} \mathrm{H}_{\mathrm{B}}\right), 3.87(1 \mathrm{H}, \mathrm{dd}, J=2.6$, 4.0, $\mathrm{CHOCH}_{2}$ ), 7.25-7.45 (5H, m, Ph); ${ }^{13} \mathrm{C}-\mathrm{NMR}(125.7 \mathrm{MHz}$, $\left.\mathrm{CDCl}_{3}\right) \delta 51.2,52.3,125.5,128.2,128.5,137.5 ; \mathrm{MS} m / z$ (rel. int): $121\left[\mathrm{M}^{+}+1\right](3), 120\left[\mathrm{M}^{+}\right](32), 119(43), 92$ (30), 91 (100), 90 (47), 89 (57), 77 (6), 65 (15), 63 (16), 51 (10) [2]; GC-MS $t_{R}=5.475 \mathrm{~min} ;[\propto]_{D}^{20}=0(c 0.10$, ethyl acetate $)$.

Cyclohexene Oxide. The inlet temperature was set at $280^{\circ} \mathrm{C}$. Oven temperature programme was $50^{\circ} \mathrm{C}$ for $5 \mathrm{~min}$ and ramped to $160^{\circ} \mathrm{C}$ at $10^{\circ} \mathrm{C} / \mathrm{min}$. A full SCAN data $(\mathrm{m} / z)$ was performed in a mass range of 45-160. The SIM analysis was performed by observing ions at $(\mathrm{m} / z=41.1,53.1,54.1,67.1$, 79.1, 81.1, 82.1) for cyclohexene and $(m / z=54.1,55.1,57.1,69.1$, 83.1) for cyclohexene oxide, respectively.

Cyclohexene Oxide. Yield 75\%; colourless liquid; IR $v_{\max }$ $\left(\mathrm{cm}^{-1}\right):$ 2926, 2855, 1363, 954, 883, 797; ${ }^{1} \mathrm{H}-\mathrm{NMR}(500 \mathrm{MHz}$, $\left.\mathrm{CDCl}_{3}\right) \delta$ 1.15-1.32 (2H, m, $\left.\mathrm{CH}_{2}-\mathrm{CH}_{2}\right), 1.36-1.49(2 \mathrm{H}, \mathrm{m}$, $\left.\mathrm{CH}_{2}-\mathrm{CH}_{2}\right), 1.75-1.87\left(2 \mathrm{H}, \mathrm{m}, \mathrm{CH}_{2}\right), 1.88-2.02\left(2 \mathrm{H}, \mathrm{m}, \mathrm{CH}_{2}\right)$, $3.11(2 \mathrm{H}, \mathrm{m}, \mathrm{CHOCH}) ;{ }^{13} \mathrm{C}-\mathrm{NMR}\left(125.7 \mathrm{MHz}, \mathrm{CDCl}_{3}\right) \delta 19.4$, 24.5, 52.2 [22]; MS m/z (rel. int): $98\left[\mathrm{M}^{+}\right]$(4), 97 (14), 83 (100), 69 (31), 57 (30), 55 (40), 54 (43) [2], GC-MS $t_{R}=7.359 \mathrm{~min}$; $[\propto]_{D}^{20}=0$ (c 0.10 , ethyl acetate).

1-Methylcyclohexene Oxide. The inlet temperature was at $280^{\circ} \mathrm{C}$. Initial $\mathrm{GC}$ oven temperature was $50^{\circ} \mathrm{C}$ for $4 \mathrm{~min}$ and then ramped to $160^{\circ} \mathrm{C}$ at $10^{\circ} \mathrm{C} / \mathrm{min}$, and carrier gas flow rate$1 \mathrm{~mL} / \mathrm{min}$. A full SCAN data $(\mathrm{m} / z)$ was performed in a mass range of 45-160. For SIM Quantitative method: a group of ions was monitored in 1-methylcyclohexene (67.1, 68.1, 81.1, 96.2) and 1-methylcyclohexene oxide (55.1, 67.1, 69.1, 83.1, 97.1).

1-Methylcyclohexene Oxide. Colourless liquid; IR $v_{\max }\left(\mathrm{cm}^{-1}\right)$ : 2927, 2861, 1450, 872, 835, 759; ${ }^{1} \mathrm{H}-\mathrm{NMR}\left(500 \mathrm{MHz}, \mathrm{CDCl}_{3}\right) \delta$ 1.10-1.32 (2H, m), $1.29\left(3 \mathrm{H}, \mathrm{s}, \mathrm{CH}_{3}\right), 1.34-1.48\left(2 \mathrm{H}, \mathrm{m}, \mathrm{CH}_{2}\right)$, 1.61-1.69 (1H, m, $\left.\mathrm{CH}_{2}\right), 1.78-1.94\left(3 \mathrm{H}, \mathrm{m}, \mathrm{CH}_{2}\right), 2.95$ (1H, br.d, $\mathrm{CH}) ;{ }^{13} \mathrm{C}-\mathrm{NMR}\left(125 \mathrm{MHz}, \mathrm{CDCl}_{3}\right) \delta 19.9,20.3,24.2,24.9,30.1$, 57.8, 59.8 [22]; $\mathrm{MS} m / z$ (rel. int): $113\left[\mathrm{M}^{+}+1\right](1), 112\left[\mathrm{M}^{+}\right](13)$, 97 (100), 83 (53), 71 (20), 69 (30), 68 (20), 67 (25), 55 (72) [2]; GC-MS $t_{R}=6.480 \mathrm{~min} ;[\propto]_{D}^{20}=0$ (c 0.10, ethyl acetate).
Phenylacetic Acid. For inlet, injector volume $=1 \mu \mathrm{L}$, injector port temperature $=280^{\circ} \mathrm{C}$, and splitless mode were used. The oven temperature was $50^{\circ} \mathrm{C}$ for $0 \mathrm{~min}$; then it was increased to $260^{\circ} \mathrm{C}$ by $10^{\circ} \mathrm{C} / \mathrm{min}$. The epoxide was discovered by mass spectrometer detector operated at thermal aux temperature $=$ $280^{\circ} \mathrm{C}$ with helium as a carrier gas, and flow rate $=0.9 \mathrm{~mL} /$ $\min$.

Phenylacetic Acid. Pale yellow solid; ${ }^{1} \mathrm{H}-\mathrm{NMR}(500 \mathrm{MHz}$, $\left.\mathrm{CDCl}_{3}\right) \delta 3.57\left(2 \mathrm{H}, \mathrm{s}, \mathrm{CH}_{2}\right), 7.17-7.29(5 \mathrm{H}, \mathrm{m}, \mathrm{Ph}) ;{ }^{13} \mathrm{C}-\mathrm{NMR}$ $\left(125 \mathrm{MHz}, \mathrm{CDCl}_{3}\right) \delta 41.2,127.5,128.8,129.5,133.3,178.1$ [25]; MS $m / z$ (rel. int): $137\left[\mathrm{M}^{+}+1\right]$ (4), $136\left[\mathrm{M}^{+}\right]$(39), 92 (19), 91 (100), 65 (16); GC-MS $t_{R}=7.927 \mathrm{~min}$.

\section{Conclusion}

Overall, the use of phenylacetic acid gave epoxide ranging from reasonable to good yields when compared to those reported when using strong carboxylic acids such as acetic acid and formic acid. Moreover, the recyclability result is very overwhelming, rendering this epoxidation method one of the best methods ever described. The method also revealed that only a mild operating temperature $\left(35^{\circ} \mathrm{C}\right)$ and a milligramscale of Novozym 435 (19.9 mg) were required to give higher catalytic activity towards the acid peroxidation process and limit the enzyme deactivation by $\mathrm{H}_{2} \mathrm{O}_{2}$. In this way, we found that the scope of the reaction can be extended particularly for industrial application.

\section{Conflict of Interests}

The authors declare no conflict of interest. The authors alone are responsible for the content and writing of the paper.

\section{Acknowledgments}

The authors would like to thank the financial support from the Ministry of Higher Education (MOHE) through FRGS and a Graduate Research Fellowship (GRF) from the Universiti Putra Malaysia (UPM).

\section{References}

[1] G. Sienel, R. Reith, and K. T. Rowbottom, Ullmann's Encyclopaedia of Organic Chemicals, Wiley-VCH, Weinheim, Germany, 1999.

[2] C. Wiles, M. J. Hammond, and P. Watts, “The development and evaluation of a continuous flow process for the lipase-mediated oxidation of alkenes," Beilstein Journal of Organic Chemistry, vol. 5, article 27, pp. 1-12, 2009.

[3] B. A. Bhat, S. C. Puri, M. A. Qurishi, K. L. Dhar, and G. N. Qazi, "Synthesis of 3,5-diphenyl-1H-pyrazoles," Synthetic Communications, vol. 35, no. 8, pp. 1135-1142, 2005.

[4] S. Dinda, A. V. Patwardhan, V. V. Goud, and N. C. Pradhan, "Epoxidation of cottonseed oil by aqueous hydrogen peroxide catalysed by liquid inorganic acids," Bioresource Technology, vol. 99, no. 9, pp. 3737-3744, 2008.

[5] H. Xipu, D. Xia, W. Sengsheng, X. Jun, and G. U. Yuxiang, "Catalytic epoxidation of soybean oil methyl esters," Advanced Materials Research, vol. 396-398, pp. 833-836, 2012. 
[6] F. Bjorkling, H. Frykman, S. E. Godtfredsen, and O. Kirk, "Lipase catalyzed synthesis of peroxycarboxylic acids and lipase mediated oxidations," Tetrahedron, vol. 48, no. 22, pp. 45874592, 1992.

[7] C. Orellana-Coca, J. M. Billakanti, B. Mattiasson, and R. HattiKaul, "Lipase mediated simultaneous esterification and epoxidation of oleic acid for the production of alkylepoxystearates," Journal of Molecular Catalysis B: Enzymatic, vol. 44, no. 3-4, pp. 133-137, 2007.

[8] W. S. D. Silva, A. A. M. Lapis, P. A. Z. Suarez, and B. A. D. Neto, "Enzyme-mediated epoxidation of methyl oleate supported by imidazolium-based ionic liquids," Journal of Molecular Catalysis $B$, vol. 68, no. 1, pp. 98-103, 2011.

[9] J. M. R. Silva, T. B. Bitencourt, M. A. Moreira, and M. G. Nascimento, "Enzymatic epoxidation of Beta-caryophyllene using free or immobilized lipases or mycelia from Amazon region," Journal of Molecular Catalysis B, vol. 95, pp. 48-54, 2013.

[10] C. Zou, Y. Liu, Y. Qin, A. Tang, and L. Lan, "Chemoenzymatic epoxidation of a-pinene catalyzed by Novozym 435," Advanced Materials Research, vol. 634-638, pp. 896-900, 2013.

[11] C. Orellana-Coca, S. Camocho, D. Adlercreutz, B. Mattiasson, and R. Hatti-Kaul, "Chemo-enzymatic epoxidation of linoleic acid: parameters influencing the reaction," European Journal of Lipid Science and Technology, vol. 107, no. 12, pp. 864-870, 2005.

[12] G. Grigoropoulou, J. H. Clark, and J. A. Elings, "Recent developments on the epoxidation of alkenes using hydrogen peroxide as an oxidant," Green Chemistry, vol. 5, no. 1, pp. 1-7, 2003.

[13] E. Abdulmalek, M. Arumugam, M. B. A. Rahman, M. Basri, and A. B. Salleh, "Enzyme-facillitated synthesis of 1-nonene oxide and simple GC-MS SIM method for rapid screening of epoxidation processes," Biocatalysis and Biotransformation, vol. 30, pp. 5-6, 2012.

[14] E. Abdulmalek, M. Arumugam, M. B. A. Rahman, and M. Basri, "Optimization of lipase-mediated synthesis of 1-nonene oxide using phenylacetic acid and hydrogen peroxide," International Journal of Molecular Sciences, vol. 13, pp. 13140-13149, 2012.

[15] M. Rusch Gen Klaas and S. Warwel, "Chemoenzymatic epoxidation of alkenes by dimethyl carbonate and hydrogen peroxide," Organic Letters, vol. 1, no. 7, pp. 1025-1026, 1999.

[16] J.-E. So, S.-H. Kang, and B.-G. Kim, "Lipase-catalyzed synthesis of peptides containing D-amino acid," Enzyme and Microbial Technology, vol. 23, no. 3-4, pp. 211-215, 1998.

[17] L. Hedstrom, "Serine protease mechanism and specificity," Chemical Reviews, vol. 102, no. 12, pp. 4501-4523, 2002.

[18] S. C. Laha and R. Kumar, "Selective epoxidation of styrene to styrene oxide over TS-1 using urea-hydrogen peroxide as oxidizing agent," Journal of Catalysis, vol. 204, no. 1, pp. 64-70, 2001.

[19] V. V. Costa, K. A. da Silva Rocha, I. V. Kozhevnikov, and E. V. Gusevskaya, "Isomerization of styrene oxide to phenylacetaldehyde over supported phosphotungstic heteropoly acid," Applied Catalysis A, vol. 383, no. 1-2, pp. 217-220, 2010.

[20] K. Sarma, N. Borthakur, and A. Goswami, "A rapid 1,2dihydroxylation of alkenes using a lipase and hydrogen peroxide under microwave conditions," Tetrahedron Letters, vol. 48, no. 38, pp. 6776-6778, 2007.

[21] Y. Xu, N. R. B. J. Khaw, and Z. Li, "Efficient epoxidation of alkenes with hydrogen peroxide, lactone, and lipase," Green Chemistry, vol. 11, no. 12, pp. 2047-2051, 2009.

[22] E. G. Ankudey, H. F. Olivo, and T. L. Peeples, "Lipase-mediated epoxidation utilizing urea-hydrogen peroxide in ethyl acetate," Green Chemistry, vol. 8, no. 10, pp. 923-926, 2006.
[23] M. H. Hashemi and D. K. Khoshabro, "Epoxidation of terminal olefin by oxygen catalysed by a mixture of manganese and cobalt salts of $p$-aminobenzoic acid supported on silica gel," Journal of Chemical Research S, no. 10, pp. 662-663, 2004.

[24] S. K. Maiti, S. Dinda, and R. Bhattacharyya, "Unmatched efficiency and selectivity in the epoxidation of olefins with oxodiperoxomolybdenum(VI) complexes as catalysts and hydrogen peroxide as terminal oxidant," Tetrahedron Letters, vol. 49, no. 43, pp. 6205-6208, 2008.

[25] G.-B. Zhou, P.-F. Zhang, and Y.-J. Pan, "A novel method for synthesis of arylacetic acids from aldehydes, $\mathrm{N}-(2,3,4,6$ tetra-O-pivaloylated-D-glucopyranosyl)amine and trimethylsilylcyanide," Tetrahedron, vol. 61, no. 23, pp. 5671-5677, 2005. 

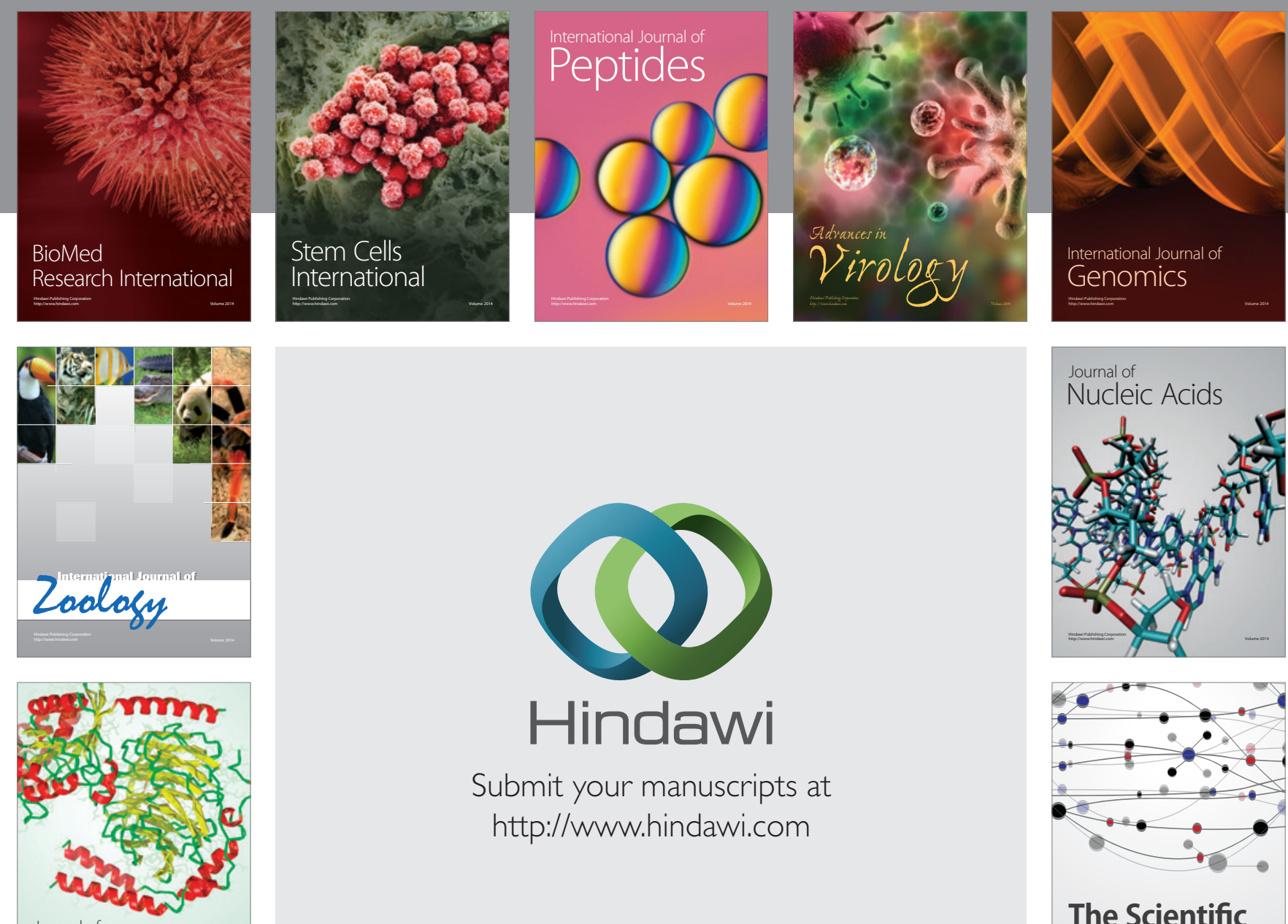

Submit your manuscripts at

http://www.hindawi.com

Journal of
Signal Transduction
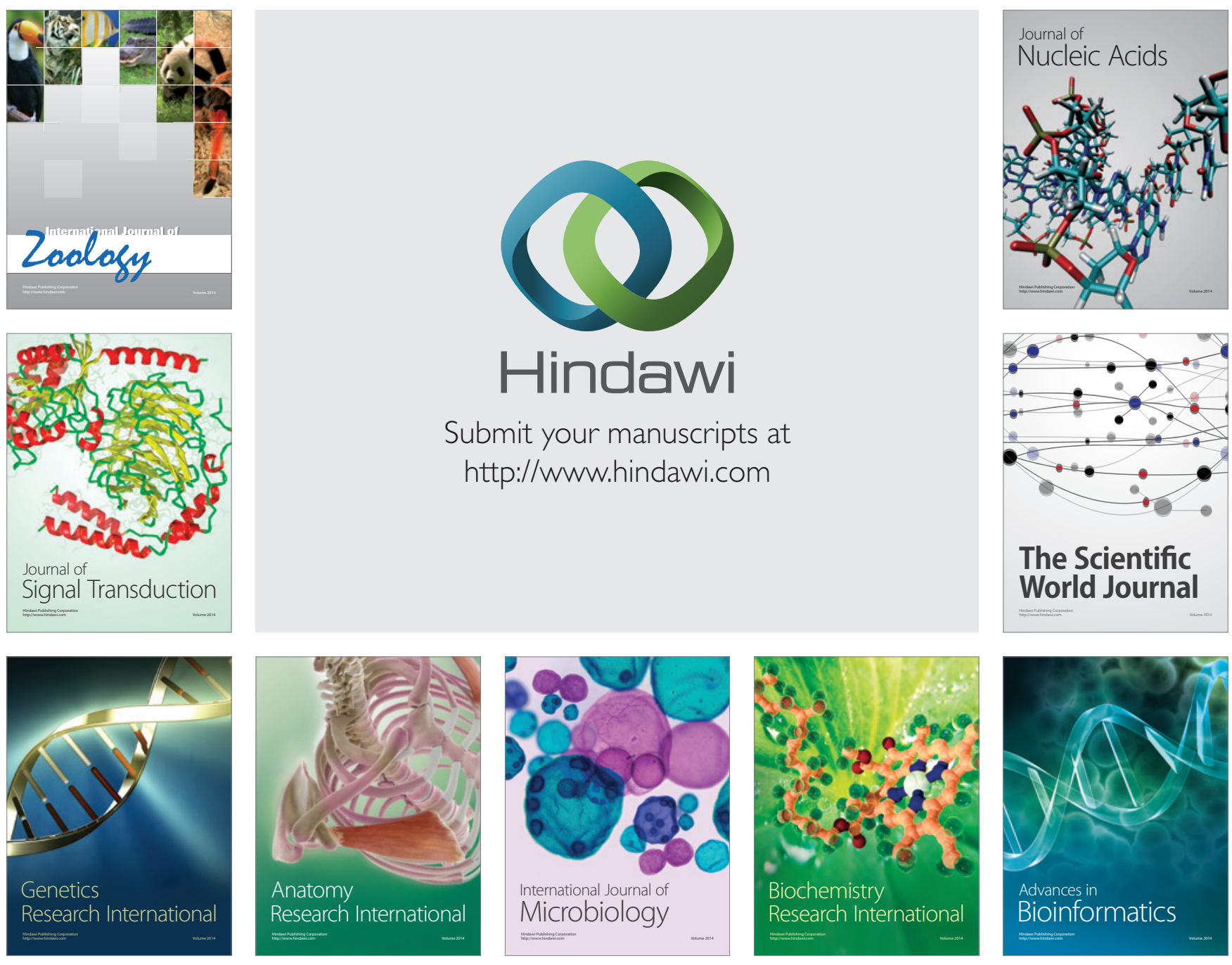

The Scientific World Journal
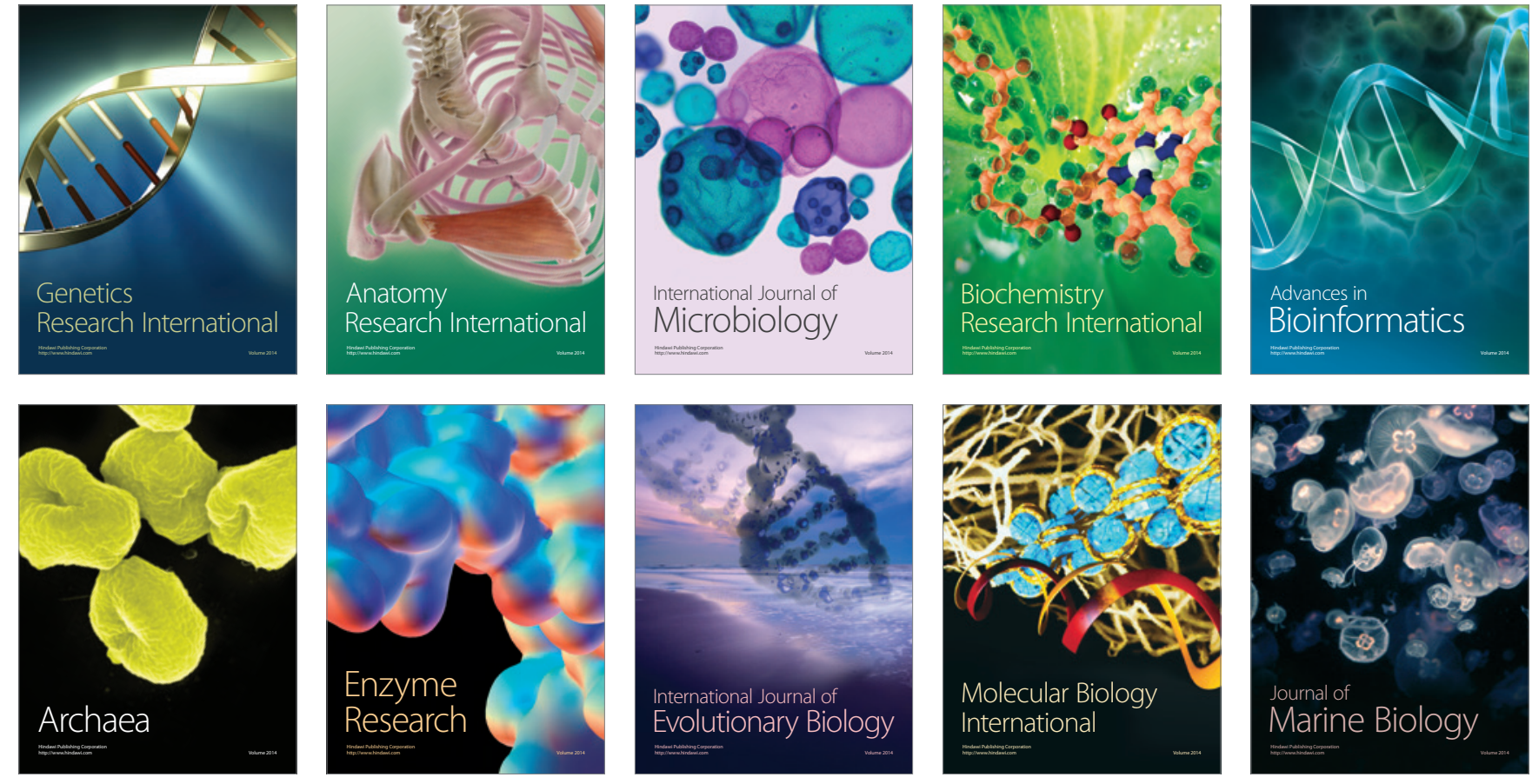